\title{
QUICK START-UP OF MUDANJIANG WASTEWATER TREATMENT PLANT AND FACTORS INFLUENCING PHOSPHOROUS REMOVAL
}

\author{
P. HUANG ${ }^{1 *}$ \\ S. QIN ${ }^{1}$ \\ Q. ZHAO ${ }^{1}$ \\ X. GUO ${ }^{2}$
}

Selected from papers presented in $9^{\text {th }}$ International Conference on Environmental

Science and Technology (9CEST2005)

1-3 September 2005, Rhodes island, Greece
${ }^{1}$ School of Municipal and Environmental Engineering Harbin Institute of Technology, 202 Haihe Road Harbin, 150090, China

${ }^{2}$ Department of environment science and engineer Zhongkai University of Agriculture and Technology

Guangzhou, 510225 ,China

*to whom all correspondence should be addressed e-mail: huangpeng1976@yahoo.com

\begin{abstract}
Successful start-up of a full-scale wastewater treatment plant (WWTP) is a key issue for the succeeding operation of WWTP on the one hand and the nutritious phosphorus removal is of great concern on the other. After the construction of Mudanjiang WWTP with a flow rate of $100,000 \mathrm{~m}^{3} \mathrm{~d}^{-1}$ in Heilongjiang Province of China, a novel way of start-up through feeding wastewater continuously into the system was attempted against the conventional start-up method of inoculating activated sludge in the aeration tank by feeding wastewater intermittently. Activated sludge was cultivated and proliferated in the aeration tanks instead of dosing acclimated sludge from other source. After one-month's start-up operation, MLSS, SV and SVI increased to $2.5 \mathrm{~kg} \mathrm{~m}^{-3}, 30 \%$ and nearly $80 \%$ respectively, which indicated that quick and simple start-up had been achieved. After successful start-up, an investigation into phosphorus removal was conducted with the emphasis on influencing factors such as ORP and NOx-N concentration etc. When the aeration tank was switched from aerobic to anaerobic mode, phosphorus removal efficiency of $80 \%$ could be realized within the whole treatment system. Experimental results revealed that an ORP of $-140 \mathrm{mV}$ and $\mathrm{NO}_{\mathrm{x}} \mathrm{N}$ of $2 \mathrm{mg} \mathrm{l}^{-1}$ were critical for the anaerobic phosphorus release, and DO in the range of $1.7-2.5 \mathrm{mg} \mathrm{l}^{-1}, \mathrm{BOD}_{5} / \mathrm{TP}$ of 20-30 and SVI of 70 80 as well as SRT of 5 days were the optimal phosphorus removal conditions for the aeration tanks.
\end{abstract}

KEYWORDS: biological phosphorus removal; anaerobic; aerobic; start-up; wastewater treatment plant

\section{INTRODUCTION}

The conventional way of start-up of a full-scale wastewater treatment plant (WWTP) is to 
inoculate a large amount of fresh activated sludge to the aeration tank and acclimate the sludge for the high removal of COD and nutrient such as nitrogen and phosphorus [1]. Although inoculating activated sludge with intermittent wastewater feeding has been a proven technology widely adopted [2] during start-up, it is estimated that 600 tons of activated sludge with water content of $80 \%$ will be needed for Mudanjiang WWTP start-up to attain half of the designed MLSS in aeration tanks, which brings great difficulty in transportation of activated sludge and consumes strong manual power. Therefore, there is a demand for finding a quick way of WWTP start-up after its construction.

For the WWTP near rivers and closed water bodies in urbanized areas, there are growing demands for the introduction of advanced treatment processes for both nitrogen and phosphorus removal, because both nitrogen and phosphorus are considered as the major elements for algal bloom in most internal waters [3]. As is well-known, biological processes for phosphorous removal from wastewater are gaining interest as an effective alternative to physical-chemical precipitation [4]. These processes are based on "luxury uptake" and "over plus accumulation", which express the ability of a biological sludge, submitted to cyclic anaerobic/aerobic conditions, to accumulate phosphorus in excess with respect to its necessities in the presence of oxygen [5].

The scope of this study is to find a novel start-up way of Mudanjiang WWTP through feeding wastewater continuously into the system against the conventional start-up method of inoculating activated sludge in the aeration tank by feeding wastewater intermittently. Special microorganisms such as phosphorus accumulating organisms (PAOs) survived and expressed strong de-phosphorous capacity during start-up process are also examined. Besides, the factors influencing phosphorous removal during steady operation are also investigated.

\section{MATERIALS AND METHODS}

\section{Wastewater Characteristics}

The Mudanjiang WWTP was designed to treat the municipal wastewater of a flow rate of $100,000 \mathrm{~m}^{3} \mathrm{~d}^{-1}$ The characteristics of raw wastewater quality are summarized in Table 1.

Table 1. Characteristics of wastewater quality in Mudanjiang WWTP

\begin{tabular}{cc}
\hline Parameter & Value (mean) \\
\hline $\mathrm{COD}_{\left(\mathrm{mg} \mathrm{l}^{-1}\right)}$ & 400 \\
$\mathrm{BOD}_{5}\left(\mathrm{mg} \mathrm{l}^{-1}\right)$ & 100 \\
$\mathrm{SS}\left(\mathrm{mg} \mathrm{l}^{-1}\right)$ & 200 \\
$\mathrm{TN}\left(\mathrm{mg} \mathrm{l}^{-1}\right)$ & 20 \\
$\mathrm{TP}\left(\mathrm{mg} \mathrm{l}^{-1}\right)$ & 4 \\
$\mathrm{NH}_{4}^{+}-\mathrm{N}\left(\mathrm{mg} \mathrm{l}^{-1}\right)$ & 11 \\
\hline
\end{tabular}

\section{Wastewater Treatment Processes of Mudanjiang WWTP}

The schematic of the Mudanjiang WWTP is shown in Figure 1. The system mainly consists of anaerobic ditch and the subsequent aerobic ditches, which is the so-called enhanced biological phosphorous removal (EBPR) [6]. The innovative features of this system are to realize phosphorous removal by intermittent aeration and to create alternative anaerobic and aerobic condition in the whole system. 


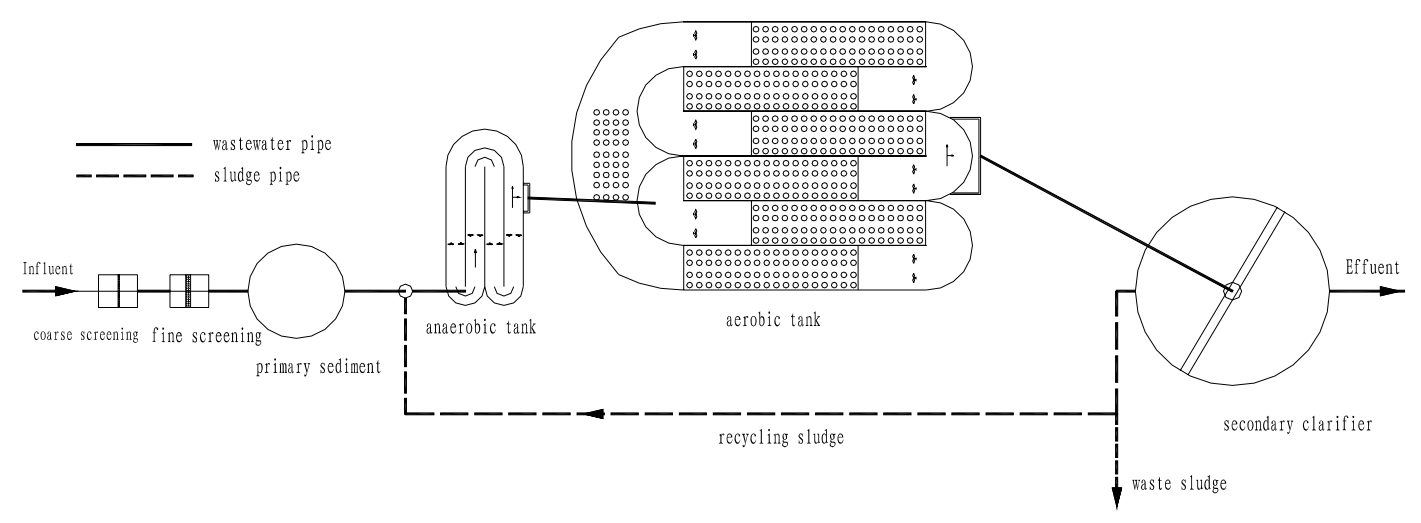

Figure 1. Schematic of Mudanjiang WWTP

\section{Start-up operation}

Temperature is one of the most important factors influencing microorganism growth and metabolism activity. It has been proven in some experiments that bacterial DNA will reach to its highest content at $20^{\circ} \mathrm{C}$, which indicates that the highest amount and activity of microorganism within activated sludge has been obtained at this temperature condition because microorganism is proportional to DNA content. Besides, under the appropriate operating conditions such as sufficient DO as well as plentiful nutrients in wastewater, such microorganism as floc-forming bacteria will thereby select gradually and grow to dominance [7] in the form of activated sludge.

On the basis of the above-mentioned consideration, the Mudanjiang WWTP was started up in the middle of May because wastewater temperature was about $20^{\circ} \mathrm{C}$. Wastewater flow rate was controlled at $1667 \mathrm{~m}^{3} \mathrm{~h}^{-1}$ (i.e. $40,000 \mathrm{~m}^{3} \mathrm{~d}^{-1}$ ) in the first 10 days and then was increased to $2900 \mathrm{~m}^{3} \mathrm{~h}^{-1}$ (i.e. about $70,000 \mathrm{~m}^{3} \mathrm{~d}^{-1}$ ) for the following 7 days. After trial operation of 17 days, flow rate was increased to the design value of $4200 \mathrm{~m}^{3} \mathrm{~h}^{-1}$ (i.e. about $100,000 \mathrm{~m}^{3} \mathrm{~d}^{-1}$ ). After another 5 days' operation, the secondary clarifier effluent met the designated discharge standard, which indicated the success of system start-up.

During the start-up period, DO concentration was kept at $8 \mathrm{mg} \mathrm{l}^{-1}$ at the nearby of the inlet for the first 4 days then decreased gradually to keep at 2.0-3.0 $\mathrm{mg} \mathrm{l}^{-1}$ thereafter. The return rate of activated sludge was set at $100 \%$ of influent. When the MLSS concentration reached the design value, excess sludge was discharged from secondary clarifier. Sludge return rate was decreased to $70 \%$ after 15 days and further decreased to $50 \%$ after another 5 days. The concentration of the return activated sludge was about $8500 \mathrm{mg} \mathrm{l}^{-1}$. Good effluent quality and activated sludge characteristics further demonstrated the success of process start-up within one month.

\section{Analytical methods}

During system start-up, such parameters as COD, MLSS, SV, SVI and microorganism species were monitored daily. When the system ran steadily, the parameters of COD, DO, volatile fatty acid (VFA), T-P and $\mathrm{NO}_{\mathrm{X}}-\mathrm{N}$ for both influent and effluent were analyzed according to the standard methods. 


\section{RESULTS AND DISCUSSION}

\subsection{Biomass increase during system start-up}

During system star-up, biomass increase is of great concern for a biological treatment system. Therefore, both MLSS and SVI were measured during start-up with the variations of MLSS and SVI shown in Fig. 2 and 3, respectively. Within the first 7 days of start-up (Figure 2), MLSS in aeration tanks increased very slowly because of poor sludge settle ability (Figure 3), too much inorganic component and some activated sludge escaped out from clarifier with effluent. As the flow rate increased after 10 days start-up running, wastewater nutrients were enough for floc-forming bacteria to proliferate and growth and MLSS increased apparently. After 22 days' operation, MLSS concentration was about $2500 \mathrm{mg} \mathrm{I}^{-1}$ and SVI was 70-80 respectively, which indicated the successful start-up and the realization of steady operation.

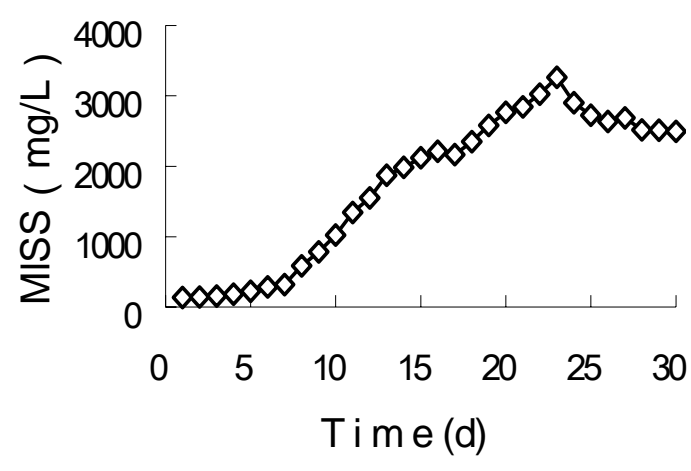

Figure 2. MLSS variation during system start-up

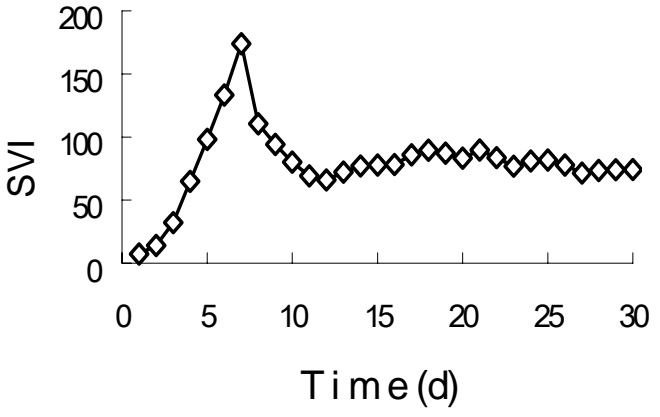

Figure 3. SVI variation during system start-up

\subsection{Microbial species found in the biological treatment system}

During system start-up, there was an abundance of microorganism found in the activated sludge within the system. Protozoa survived in the activated sludge were mainly sarcodina such as Mastigamoeba invertans (Figure 4a), Actinophrys and Filamoeba nolandi (Figure 4b). When biomass increased in the middle stage of start-up, a large amount of flagellate emerged and the dominant species were Bodo alexeieffii and Cercomonas. At the end of start-up, ciliates such as Pparamecium, Litonotus (Figure 4c) and Vorticella (Figure 4e) appeared to be the main protozoa. After the start-up process and system was operated at a steady state with an effluent meeting the discharge standard, protozoan were mainly Vorticella, Rotaria (Figure 4f) and Opercularia

\subsection{VFA effect on phosphorous removal}

Biological phosphorus removal is initiated in the anaerobic zone where acetate (and propionate) is taken up by phosphorus-storing bacteria and converted to carbon storage products that provide energy for growth in the subsequent aerobic zones [8]. The readily biodegradable COD ( $r b C O D$ ) is the primary source of VFA for the phosphorus-storing bacteria [9]. The conversion of rbCOD to VFA occurs quickly through fermentation and generally $7-10 \mathrm{mg}$ of acetate results in about $1 \mathrm{mg} \mathrm{P}$ removal, which means that the more acetate, the more cell growth, and thus, more phosphorous removal are obtained [10].

The influent COD of Mudanjiang WWTP was less than the design value of $400 \mathrm{mg} \mathrm{l}^{-1}$, which 
led to the effluent TP more than $1 \mathrm{mg} \mathrm{I}^{-1}$ owing to the VFA shortage. To raise the VFA concentration, the hydraulic retention time was extended to 3 days for the primary sedimentation tank from the beginning of July so that primary sedimentation might function as fermentation unit before primary sludge waste. As show in Fig. 5, the conversion of COD to VFA was significant. As a result, VFA/COD was increased from 0.1 to 0.25 and TP of effluent decreased from above $1.0 \mathrm{mg} \mathrm{I}^{-1}$ to $0.5 \mathrm{mg} \mathrm{I}^{-1}$, correspondingly

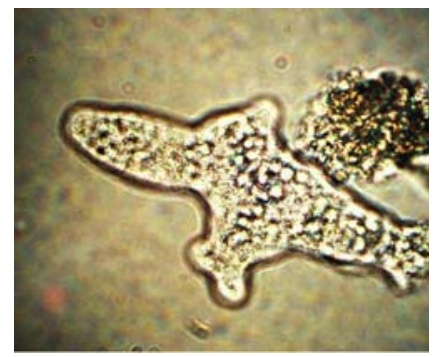

(a) Mastigamoeba invertans

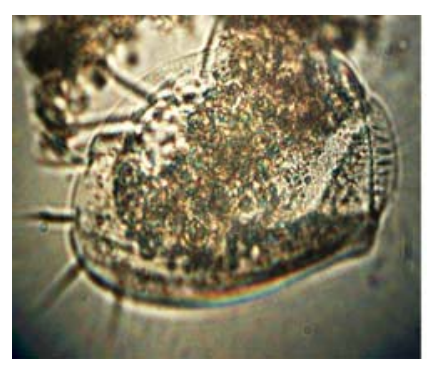

(d) Aspidisca dentate

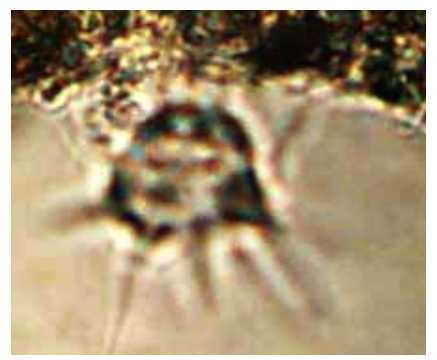

(b) Filamoeba nolandi

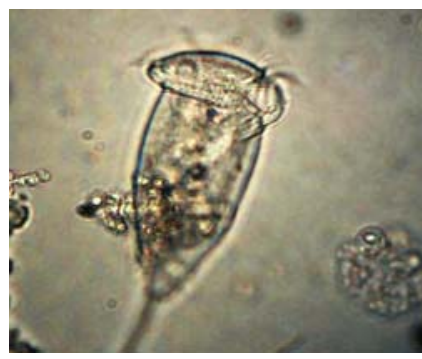

(e) Vorticella campanula

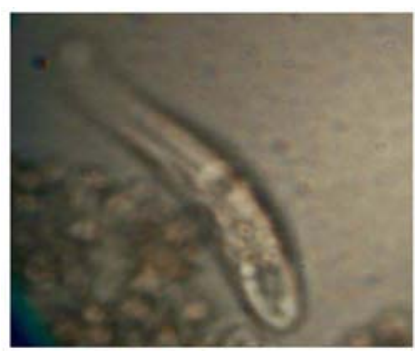

(c) Litonotus carinatus

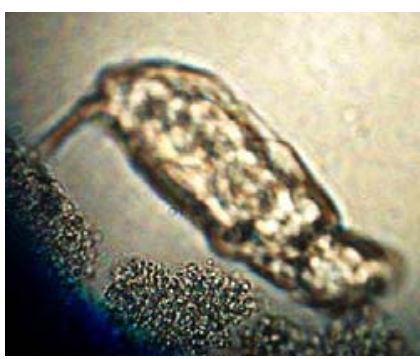

(f) rotaria

Figure 4. Microbial species found in aeration tanks

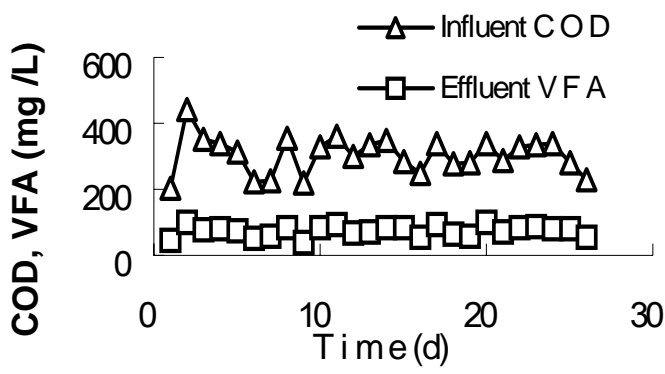

Figure 5. COD and VFA variations vs. time

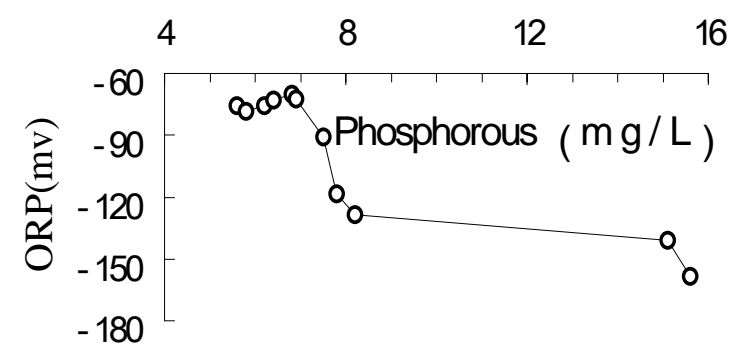

Figure 6. ORP effect on phosphorous release

ORP is related to the energy released through POM bio-chemical process. ORP value changes with the concentration variations of electron accepter, reactant and products. ORP can reflect POM activity during anaerobic phosphorous release. POM uptake phosphorous when OPR value are positive and vice versa [11]. It has been proven in some studies that PHB accumulate rapidly in the cell when ORP are below $-100 \mathrm{mV}$ and poly-phosphorate granule in wastewater decrease quickly.

Fig.6 shows that slight ORP variation will not cause great change of phosphorous concentration when ORP is below $-140 \mathrm{mV}$. When ORP value was above $-140 \mathrm{mV}$ however, 
phosphorous concentration in wastewater increases greatly. This phenomenon indicated that ORP of $-140 \mathrm{mV}$ is a turning point for phosphorous concentration variation.

\subsection{NOx-N effect on phosphorous release}

When NOx-N concentration increased, the residual phosphorous concentration decreased (Fig. 7), which meant that no phosphorous were released when high concentration of NOx-N was present. This is caused by ORP increase because of NOx-N existing in the anaerobic zone. Significant amounts of nitrate enter the anaerobic zone, the acetate also can be depleted before it is taken up by the PAOs, and treatment progress will be hindered.

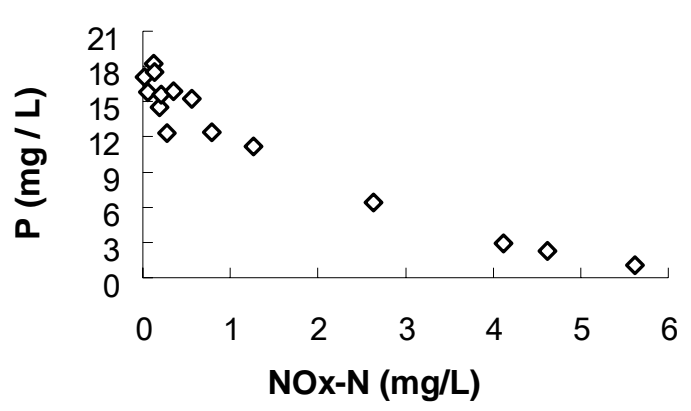

Figure 7. NOx-N effect on phosphorous release

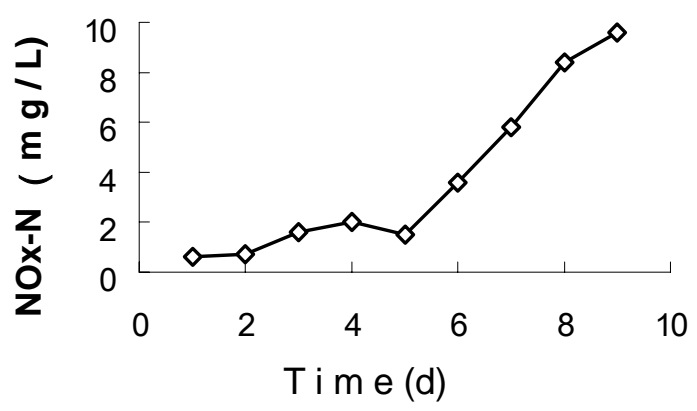

Figure 9. NOx-N concentration in anaerobic zone

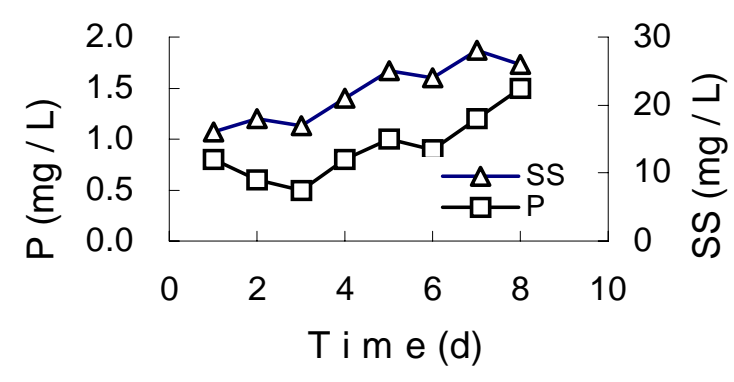

Figure 8. phosphorous and SS relatio when DO was 3-4 $\mathrm{mg} \mathrm{I}^{-1}$

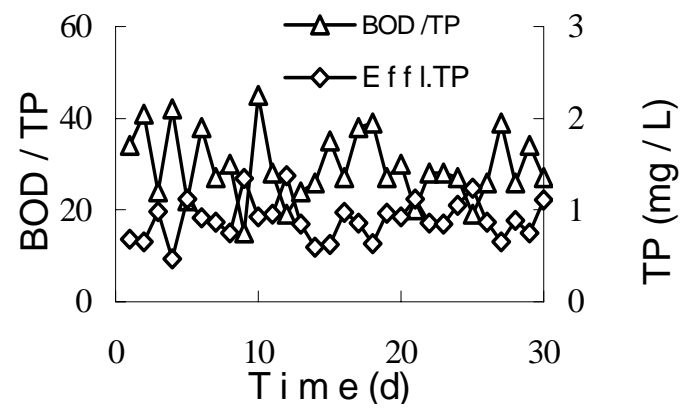

Figure 10. Relationship betweeBOD/TP and effluent TP when DO was 3-4 $\mathrm{mg} \mathrm{l}^{-1}$

\subsection{DO concentration effect on phosphorous}

During system start-up and since then, DO concentration in aerobic zone were controlled at 3-4 $\mathrm{mg} \mathrm{l}^{-1}$, phosphorous concentration decreased within the first several days and then began to increase to above $1.0 \mathrm{mg} \mathrm{l}^{-1}$. Phosphorous and SS concentration in the secondary clarify effluent were measured and the result was shown in Fig.8. Simultaneously, NOx-N concentration in anaerobic zone was also measured (Fig. 9) It can be noted in Fig. 8 and Fig. 9 that high level of DO will result in the increase of effluent SS and NOx-N concentration in anaerobic zone as well as low efficiency of phosphorous removal.

As is known, nitrification will take place in aerobic zone when extra DO exists. Sludge return to anaerobic zone will release the $\mathrm{NO}_{\mathrm{x}} \mathrm{N}$, the available DO of sludge will make ORP increase in this zone. As described above, phosphorous release will be restrained. High DO concentration in aerobic zone can also make activated sludge grow at an endogenous 
respiration stage, which leads to cell lysis and phosphorous release. Agglomerate capability of activated sludge are also weakened, granular sludge suspend in wastewater and increase effluent SS.

When SS and P/VSS were $20 \mathrm{mg} \mathrm{I}^{-1}$ and $6 \%$ respectively, effluent SS have great relativity with P/VSS and effluent granular phosphorous will reach up to $1 \mathrm{mg} \mathrm{l}^{-1}$. By controlling DO at 1.7-2.5 $\mathrm{mg} \mathrm{I}^{-1}$ in aerobic zone in the later operation, phosphorous concentration may be expected to decrease to below $1.0 \mathrm{mg} \mathrm{I}^{-1}$.

\subsection{BOD/TP effect on phosphorous removal in aerobic zone}

Influent BOD/TP has great impact on phosphorous removal. Low BOD in aeration tank will lead to low-loading operation and extend aeration, PHB in the cell will be consumed excessively to maintain the metabolish balance. The capabiblity of phosphorous up-take will be restrained.

Fig.10 shows that when $\mathrm{BOD}_{5} / \mathrm{TP}$ is high in aerobic zone, effluent TP is low, and vice verse. In order to keep steady phosphorous removal efficiency and effluent TP less than $1.0 \mathrm{mg} \mathrm{l}^{-1}$, $\mathrm{BOD}_{5} / \mathrm{TP}$ should be controlled at 20-30.

\subsection{SVI effect on phosphorous removal in aerobic zone}

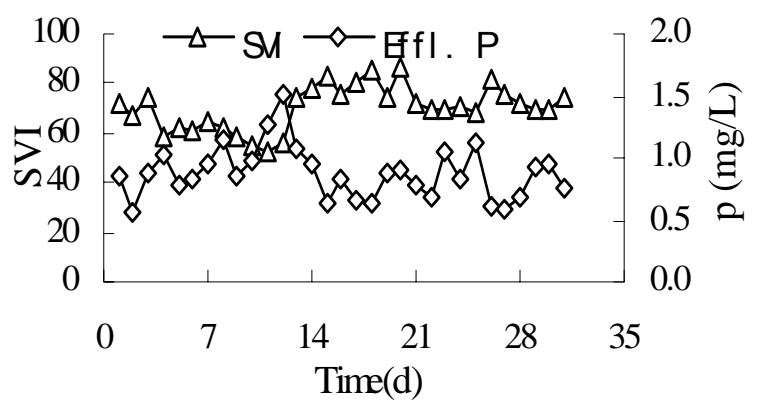

Figure 11. SVI effect on phosphorous removal

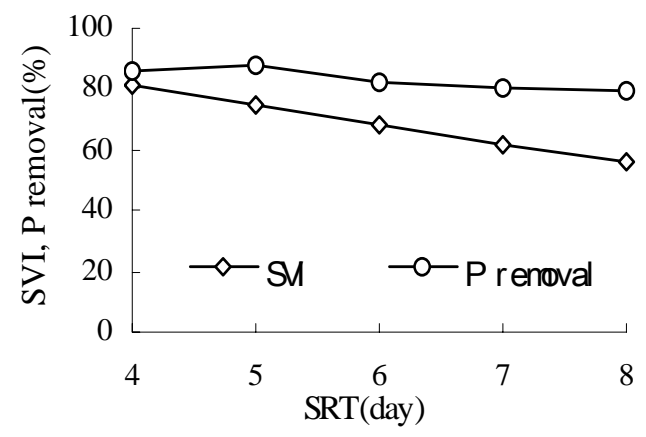

Figrue 12. SRT effect on phosphorous removal

Phosphorus removal was influenced by SVI (Figure 11). Within the first two weeks' normal operation (July 1-14), SVI was in the range of 50-70, high effluent phosphorous up to $1.6 \mathrm{mg}$ $\mathrm{I}^{-1}$ had been detected. By reducing aeration strength and shut off inlet blower to control SVI at 70-90 after July 15, however, effluent phosphoroys was below $1 \mathrm{mg} \mathrm{l}^{-1}$.

\subsection{SRT effect on phosphorous removal in aerobic zone}

Two adverse effects on phosphorous removal are associated with light loading and long SRT as show in Fig.12. This is ascribed that phosphorus removed is proportional to the amount of biological phosphorous-storing bacteria, the less phosphorous storing biomass production results in less phosphorous removal. On the other hand, the biological phosphorous bacteria are in an extended endogenous phase at longer SRT, which will deplete more of their intracellular storage products. If the intracellular glycogen is depleted, less efficient acetate and PHB storage will occur in the anaerobic zone, thus making the overall BPR process less efficient. 


\section{CONCLUSIONS}

This paper has presented a novel quick start-up procedure of full-scale Mudanjiang WWTP and affecting factors for phosphorous removal during operation. Through feeding raw wastewater into the system continuously, activated sludge were cultivated and proliferated in the aeration tanks instead of dosing acclimated sludge. The whole start-up process just took one month.

By converting primary sedimentation to primary fermentation tank and activated sludge was fermented for three days, VFA/COD was increased from 0.1 to 0.25 and effluent TP correspondingly decreased from above $1.0 \mathrm{mg} \mathrm{l}^{-1}$ to $0.5 \mathrm{mg} \mathrm{l}^{-1}$.

In the anaerobic zones, it revealed that an ORP of $-140 \mathrm{mV}$ and $\mathrm{NO}_{\mathrm{x}}-\mathrm{N}$ of $2 \mathrm{mg} \mathrm{l}^{-1}$ were critical points for the anaerobic phosphorus release. For the better phosphorus removal, DO should be maintained in the range of $1.7 \sim 2.5 \mathrm{mg} \mathrm{l}^{-1}$ in aerobic zones, $\mathrm{BOD}_{5} / \mathrm{TP}$ ratio in 20 30 and SVI in 70 90, SRT for 5 days, respectively

\section{REFERENCES}

1. Otgaard K., Christensson, M., Lie E., Jönsson K. (1997) Anoxic biological phosphorus removal in a full-scale UCT process, Wat. Res., 31(11), 2719-2726.

2. Daigger T. and Nolasco D. (1995) Evaluation and design of full-scale wastewater treatment plants using biological process models", Wat. Sci.Tech., 31(2), 245-255.

3. Kuba T., van-Loosdrecht M.C.M., Heijnen J.J. (1997) Biological dephospatation by actvated sludge under denitrifying conditions: $\mathrm{pH}$ influence and occurrence of denitrifying dephosphatation in a full-scaled waste water treatment plant, Wat. Sci. Tech., 36(12), 75-82.

4. Minp V.T. and Matsuo T. (1988) Biological mechanism of acetate uptake mediate by carbohydrate consumption in excess phosphorus removal systems, Wat. Res., 22, 565-570.

5. Hu Z-R, Wentzel M. C. (2002) Anoxic growth of phosphate-accumulating organisms (PAOs) in biological nutrient removal activated sludge systems, Wat. Res., 36, 4927-4937.

6. Leslie-Grady C P, Dagger-Glen T. (1999) Biological wastewater treatment (2nd) [M], New York:Marcel Dekker,Inc, 1999

7. Paul E., Plisson-Saune S., Mauret M. (1995) Process state evaluation of alternating oxic-anoxic activated sludge using ORP, pH,and DO, Wat. Sci. Tech, 38(3), 299-306.

8. Comeau Y., Oldham W.K. and Hall K.L. (1987) Dynamics of carbon reserves in biological dephosphatation of Wastewater, An IAWPRC specialized conference in Rome, 39-55.

9. Gerber A., Mostert E.S., Winter,C.T., and de-Villers R.H. (1986) The effect of acetate and other short-chain carbon compounds on the kinetic of biological removal, Wat. S.A. 12(1), 7-12.

10. Hu Z-R., Wentzel M.C., Ekama G.A. (2002) A general kinetic model for biological nutrient removal activated sludge system, Wat. Res., (submitted for publication).

11. Carlsson and Aspegren H. (1996) Interactions between wastewater quality and phosphorus release in the anaerobic reactor of the EBPR process, Wat. Res., 30 (6), 1517-1527.

12. Barker P.S. and Dold P. L. (1996) Denitrification behaviour in biological excess phosphorus removal activated sludge systems, Wat. Res. 30(4), 769-780.

13. Kuba T., Smolders G.J.F., van-Loosdrecht M.C.M., Heijinen J.J. (1993) Biological phosphorus removal from wastewater by anaerobic-aerobic SBR, Wat. Sci. Tech., 27(5/7), 241-252. 